Final article:

Reast, J., Lindgreen, A., Vanhamme, J., and Maon, F. (2010), "The Manchester super casino: experience and learning in a cross-sector social partnerships", Journal of Business Ethics, Vol. 94, Suppl. 1, pp. 197-218. (ISSN 0167-4544)

For full article, please contact LindgreenA@ cardiff.ac.uk

\title{
The Manchester Super Casino: Experience and Learning in a Cross-Sector Social Partnership
}

\author{
Jon Reast, University of Hull ${ }^{1}$ \\ Adam Lindgreen, University of Cardiff \& BEM Bordeaux Management School ${ }^{2}$ \\ Joëlle Vanhamme, EDHEC Business School ${ }^{3}$ \\ François Maon, IESEG School of Management ${ }^{4}$
}

\footnotetext{
${ }^{1}$ Dr. Jon Reast, Professor in Marketing, Business School, the University of Hull, Cottingham Road, Hull HU6 7RX, the UK. E-mail: j.reast@hull.ac.uk.

${ }^{2}$ For all correspondence: Dr. Adam Lindgreen, Professor in Marketing at the University of Cardiff \& research fellow at BEM Bordeaux Management School. Correspondence address: Professor Adam Lindgreen, Cardiff Business School, the University of Cardiff, Aberconway Building, Colum Drive, Cardiff CF10 3EU, the U.K. E-mail: LindgreenA@ @ardiff.ac.uk.

3 Dr. Joëlle Vanhamme, Professor in Marketing, EDHEC Business School, 24 avenue Gustave Delory, CS 50411, 59057 Roubaix Cedex 1, France. E-mail: joelle.vanhamme@edhec.edu.

${ }^{4}$ Dr. François Maon, Assistant Professor in Strategy and Corporate Social Responsibility, IESEG School of Management, 3 rue de la Digue, 59000 Lille, France. E-mail: f.maon@ieseg.fr.
} 


\title{
The Manchester Super Casino: Experience and Learning in a Cross-Sector Social
}

\section{Partnership}

\begin{abstract}
The management of cross-sector social partnerships (CSSPs) among government, business, and not-for-profit entities can be complex and difficult. This article considers the importance of organizational experience and learning for the successful development of CSSPs. By analyzing the Manchester Super Casino, this research emphasizes the significant benefits of prior experience with CSSPs that enable partners to learn and develop relationships, skills, and capabilities over time, which then have positive influences on future performance. The result is a refined learning model of the CSSP process that includes key variables for CSSP success. As such, these findings provide a template for managing complex CSSPs from the perspective of the different partner organizations.
\end{abstract}

Keywords: Greater Manchester Super Casino; corporate social responsibility; cross-sector social partnerships; organizational learning; management; philosophy; regeneration; model. 


\section{Introduction}

The increasing concerns about social issues across business environments worldwide, and the resultant emphasis on the corporate social responsibility (CSR) idea (Carroll, 2004; Gabriel, 2006; Lindgreen et al., 2009; Perrini et al., 2006), have made cross-sector social partnerships (CSSPs) or interactions ${ }^{5}$ increasingly desirable for organizations (Austin, 2000; Kanter, 1998; Korten, 1998; Seitanidi and Lindgreen, 2008; Waddock and Smith, 2000), especially those that need to burnish their CSR credentials (Seitanidi and Crane, 2009; Seitanidi and Ryan, 2007). Cross-sector social partnerships, loosely defined as collaborations by partners from two or more sectors to tackle economic and social issues, remain highly complex and difficult to manage though (London et al., 2005; Maon et al., 2009; Muthuri et al., 2009; Selsky and Parker, 2005). The involvement of several stakeholders means an organization must take multiple concerns into account when managing its various partnerships (Muthuri et al., 2009; Oxley-Green and Hunton-Clark, 2003; Selsky and Parker, 2005).

Yet CSSPs offer great potential benefits for both business and not-for-profit organizations. The former gain easier access to resources (Barringer and Harrison, 2000), enhanced reputational or social capital (Millar et al., 2004; Steckel and Simons, 1992), and increased levels of stakeholder trust and corporate legitimacy (Heugens et al., 2002; Millar et al., 2004). The nonprofit groups also enjoy increased visibility and publicity (Elkington and Fennell, 1998), easier access to financial resources, employee volunteers, and training facilities (O'Regan and Oster, 2000), and greater contributions (Muthuri et al., 2009). Furthermore, both types of organizations likely achieve organizational learning as an outcome of CSSPs (Drucker, 1989; London et al., 2005; Selsky and Parker, 2005). Partnerships offer new insights into the relevant problem, and partners learn new ways to frame problems and potential solutions (Boguslaw, 2002; Huxham and Vangen, 2000). This

\footnotetext{
${ }^{5}$ We use the term "cross-sector social partnerships" to refer to both partnerships and interactions throughout.
} 
includes, for example, societal learning that can produce innovation and change (Waddell, 1999), "reflective skills that can modify mindsets and habits" (Selsky and Parker, 2005: 858), and social, administrative, and technical abilities (Seitanidi and Crane, 2009).

Despite the clear importance of CSSPs and significant research related to them, to the best of our knowledge, only limited and indirect references have addressed the importance of prior learning for ongoing CSSP development and interactions (Seitanidi, 2007; Waddock, 1989, 1991), though such learning should have a key role in the success of CSSPs (Seitanidi, 2007; Seitanidi and Crane, 2009; Selsky and Parker, 2005). For example, government-business CSSPs change with "more experience ... and partnering moves into more fully developed policy partnerships" (Selsky and Parker, 2005: 860). Seitanidi and Crane (2009: 424) also note the importance of "a willingness to learn and adapt" for successful CSSPs. Yet Selsky and Parker (2005: 866) recognize too that "studies which show how partners overcome (or exploit) sectoral differences to learn about their social issue, learn from each other, or encourage stakeholder learning would be valuable contributions." They indicate that extant research has examined short-term partnerships but continues to "leave gaps in understanding long-term impacts, consequences and learning” for CSSPs (Selsky and Parker, 2005: 866). In particular, extant literature has not considered the impact of prior CSSP experience and learning on the development, management, and success of new initiatives. We address this lacuna by investigating the following questions: What is the impact of organizational experience and learning on the development and management of CSSPs, and how can models of CSSP practice better reflect organizational experience and learning?

We investigate a significant, complex, tri-sector CSSP (cf. Selsky and Parker, 2005), the Manchester Super Casino project, which includes government, business, and not-for-profit organizations, and thereby critically examine prior conceptualizations and models of CSSPs. With this study, we contribute by integrating organizational learning and CSSP literature, two 
well-developed streams of research that so far have not been connected satisfactorily previously. Various elements of prior CSSP literature note organizational learning in passing, but no studies have fully exploited the theoretical lenses that organizational learning offers to clarify CSSP success or support an integrated framework of the learning CSSP process.

We structure the remainder of this article as follows: First, we offer a literature review in which we both note some gaps and deficiencies in our current understanding of CSSPs and introduce organizational learning literature. This review informs our fieldwork. Second, we describe our methodology, and third, we present and discuss the findings of our study of the Manchester City Council's proposal for a regional super casino and entertainment destination, which emphasizes the importance of prior CSSP experience and organizational learning, as well as the adoption of a long-term orientation. We thus propose a new model of the learning CSSP process. Fourth, we identify some theoretical contributions and managerial implications, including a template for managing complex CSSPs from the perspective of different partner organizations. Fifth, we discuss some limitations to our study and suggest avenues for further research.

\section{Theoretical Framework}

Definitions of Cross-Sector Social Partnerships

Since the 1980s (Gray, 1989), literature on CSSPs has drawn on diverse disciplines, including collaborative strategy (Astley and Fombrun, 1983; Huxham and Vangen, 1996), CSR (Seitanidi et al., 2010; Waddock and Smith, 2000), management (Austin, 2000; Gray, 1989; Seitanidi and Crane, 2009), and organization studies (Bryson and Crosby, 2006). The use of CSSPs is increasing (Berger, Cunningham, and Drumwright, 2004; Boehm, 2005; Crane, 2000), and academic study of CSSPs has increased in parallel (Selsky and Parker 2005). Cross-sector social partnerships represent a "poorly understood phenomenon" (Googins and Rochlin, 2000: 133) and have been defined in various, and sometimes competing, ways 
(Kooiman, 1999; Nelson and Zadeck, 2000; Selsky and Parker, 2005; Waddock, 1991), as Table 1 shows. Most of these definitions include notions of cross-sector societal issues and/or benefits, with some stressing mutuality and continuity as well. For the purposes of this article, faced with no single unified definition of CSSPs, we define them as the deliberate and ongoing collaboration of partners from two or more societal sectors working to tackle mutually important social and economic issues.

\{Insert Table 1 around here $\}$

CSSP continuum of engagement. Most literature on CSSPs implies a continuum of engagement. Some authors describe two levels (Selsky and Parker, 2005), though the majority support three levels, labeled in various ways, as we show in Table 2. To simplify this array of competing labels, we note that the continuum tends to range from an introductory level to an intermediate and then an advanced level. The introductory level usually involves one-way communication and power (Grunig and Grunig, 1992), associated with a short-term, narrowly defined, self-interested orientation (Selsky and Parker, 2005). The intermediate level extends to include two-way, asymmetric communication and power balances, as well as a medium-term orientation and increased levels of mutuality. Finally, the advanced level achieves two-way, symmetric communication and power balances, is associated with the longer term, is broadly defined, and emphasizes mutuality. More CSSPs appear in introductory rather than intermediate and advanced levels (Muthuri et al., 2009; Selsky and Parker, 2005).

\{Insert Table 2 around here

We are particularly interested in whether these levels on the CSSP continuum constitute a pathway, which tends to be navigated step-by-step and thus demands time and experience. Although no research has adopted a time- and experience-based view of the levels on the continuum, it has suggested in a limited sense that CSSP partnerships might result in 
organizational learning, which then affects future interactions (Waddock, 1989, 1991). Moreover, understanding, trust, and commitment might develop over time in such relationships, which then help resolve issues of power asymmetry (Seitanidi, 2007).

Modeling CSSPs. A significant research stream reflects ongoing attempts to model CSSPs. Some models define process stages in the formation and implementation of CSSPs (Chapple and Moon, 2005; Seitanidi and Crane, 2009), whereas others adopt a more strategic level. For example, Muthuri and colleagues (2009) design a framework of corporate interactive governance, in which they include a structural level that reflects the external environmental factors that influence the development, implementation, and outcome of CSSPs, as well as an action level that reflects the interactions of the partners. This framework thus acknowledges the different preferences, intentions, and expectations of various stakeholders (Muthuri et al., 2009), but as do many other models, it only relates to CSSPs involving two sectors and assumes that each sector can be represented easily as a single unit. More process-based models draw on collaborative strategies literature, such as Waddell and Brown's (1997) fivephase model (identifying preconditions for partnership; convening partners and defining problems; setting shared directions; implementing action strategies; and institutionalizing or expanding successful intersectoral collaborations) or Seitanidi and Crane's (2009) simplified three-stage process model (partnership selection, design, and institutionalization).

Prior models also tend to be static in orientation and regard CSSP efforts as individual, $a d$ hoc initiatives that do not reflect relational or continuous interactions over time and different projects. Nor do the models contain learning loops that might capture the knowledge and adaptation that can result from current and prior CSSP interactions (Crossan et al., 1999). Overall then, existing efforts fail to capture the messiness of partnership practices with complex models (Selsky and Parker, 2005).

Organizational Learning 
For the past 40 years, organizational learning has been a key focus within management and organization research (Cangelosi and Dill, 1965; Crossan et al., 1999; Simon, 1969; Vera and Crossan, 2004). (For reviews of organizational learning, see for example Dodgson, 1993; Easterby-Smith et al., 2000; Fiol and Lyles, 1985; Levitt and March, 1988). Simon (1969: 236) defines it as "the growing insights and successful restructurings of organizational problems by individuals reflected in the structural elements and outcomes of the organization itself." Such impacts on strategic management outcomes have been widely researched and reported (e.g., Crossan and Berdrow, 2003; Fiol and Lyles, 1985; Slater and Narver, 1995), and some observers even claim organizational learning is a critical source of competitive advantage, because "the ability to learn faster than your competitors may be the only sustainable competitive advantage" (DeGeus, 1988: 71). Organizational learning thus relates positively to organizational performance (Bontis et al., 2002).

Conceptualization of organizational learning. Organizational learning takes two forms (Polanyi, 1967): tacit knowledge or learning, which is relatively intangible, often relates to habits or culture, and is difficult to capture and share (Nelson and Winter, 1982), and explicit knowledge or learning, which can be more precisely defined, documented, and communicated. These two forms support each other and influence how and what organizations learn (Polanyi, 1967). Organizational learning also encompasses a tension between new learning, or exploration, and using what already has been learned, or exploitation (March, 1991). Exploratory learning refers to discovery and experimentation with new alternatives and opportunities, whereas exploitative learning pertains to the execution, refinement, or deepening of existing competences (Brady and Davies, 2004; Dodgson, 1993; March, 1991). Organizations must balance these exploratory and exploitative elements to leverage their prior knowledge while also remaining open to new knowledge (March, 1991; Schildt et al., 2005). 
Modeling organizational learning. Among the various models and frameworks of organizational learning (Daft and Weick, 1984; March and Olsen, 1975; Nonaka and Takeuchi, 1995), the multilevel framework by Crossan and colleagues (1999) is generally well accepted. The framework, known as $4 \mathrm{i}$, reflects several key premises. In particular, it conceptualizes organizational learning as involving multiple levels within organizations, from individual to the group and then to the overall organizational level, as we depict in Figure 1.

\{Insert Figure 1 around here $\}$

These three levels of organizational learning are linked by four social and psychological processes, intuiting, interpreting, integrating, and institutionalizing (i.e., the four i), that allow for "feed-forward" from the individual to the organizational level and feedback from the organizational to the individual level.

Intuiting, which refers to "the preconscious recognition of the pattern and/or possibilities inherent in a personal stream of experience" (Crossan et al., 1999: 525), is possessed by individual members who develop novel insights based on their experience, ascertain underlying or potential patterns in that experience, and then translate their insights into metaphors that can be communicated (Lawrence et al., 2005). The second process, interpreting, relates to "the explaining, through words and/or actions of an insight or idea to one's self and to others" (Crossan et al., 1999: 525). Thus interpreting begins at the individual level and extends to include others through conversation and dialogue. Through interpreting, ideas become explicit, named, and incorporated into cognitive maps that relate the new idea to other ideas or external contexts (Lawrence et al., 2005). The third process of integrating occurs at the group level. As the "process of developing shared understanding among individuals and of taking coordinated action through mutual adjustment" (Crossan et al., 1999: 525), integrating aims to achieve coherent collective action. Finally, institutionalization implies that learning among individuals and groups gets embedded into organizations through 
"systems, structures, procedures, and strategy" (Crossan et al., 1999: 525). This process makes organizational learning distinct from individual or group learning; through institutionalizing, ideas transform into organizational institutions that are available to all members on an ongoing basis, at least somewhat independent of their individual or group origins. Together, the four processes form a learning loop.

General acceptance of this multilevel, process-based nature of organizational learning appears in prior literature (Easterby-Smith et al., 2000), and many studies in the past 10 years have either applied or refined this basic framework (Lawrence et al., 2005; Vera and Crossan, 2004). Notwithstanding such general acceptance, some authors also stress the importance of leadership styles (Beverland and Lindgreen, 2007; Slater and Narver, 1995; Vera and Crossan, 2004) and of colleagues' "approachability, credibility and trustworthiness" with regard to sharing knowledge (Andrews and Delahaye, 2000: 797), as well as the impact of the power and political status of key individuals within organizations (Lawrence et al., 2005). Additional research emphasizes the view that organizational learning depends on its history, such that organizations learn from direct experience and the indirect experience of other organizations, then develop conceptual frameworks or paradigms to interpret that experience (Levitt and March, 1988).

\section{Research Focus}

Although research efforts aimed at conceptualizing and modeling CSSPs and underlying processes have offered key insights, various gaps remain. In particular, CSSPs are still a relatively poorly understood phenomenon, and though many authors cite a continuum from introductory to advanced levels, it is not clear whether this progression constitutes a pathway to be navigated. The static models of CSSP ignore any prior experiential learning or resource benefits (tangible or intangible) by partners in prior interactions. 
On the basis of our literature review, we derive two focused research questions to guide our study and enhance our knowledge about CSSPs. We investigate these questions in the context of a government sector-led regeneration CSSP, which enables us to contribute further to extant literature. First, what is the impact of organizational experience and learning on the development and management of CSSPs? Second, how can models of CSSP practice better reflect organizational experience and learning? To answer these questions, we focus on a complex, tri-sector CSSP, in which each sector of the partnership has different interests. By determining if the partners' prior experience and learning enable the CSSP to operate at a more advanced or integrative level on the engagement continuum, we offer ideas for managing complex tri-sector CSSPs.

\section{Methodology}

The use of qualitative methods is appropriate for studying complex processes (Eisenhardt, 1989; Lindgreen, 2008; Yin, 2003). Using secondary data and multiple interviews also helps develop rich insights and provide the basis for greater transferability of the findings to other contexts (Eisenhardt, 1989). We therefore adopt these methods and employ a case approach.

\section{Case Selection and Description}

We select the tri-sector Manchester Super Casino CSSP for this research. This CSSP commenced in 2003, when the U.K. government announced the likely reclassification of gambling legislation to allow more and larger casinos. The CSSP progressed through various stages during a five-year period and culminated in 2007, when Manchester was awarded a license (in a competitive bidding process with other U.K. locations) to run the "largest casino in Europe" (Tobin Prior, CEO, Kerzner Consortium). The Manchester City Council, as the local government body responsible for the regeneration of East Manchester and the owner of the proposed site, was the focal organization. 
The complex Manchester Super Casino CSSP includes various stakeholder groups that represent governmental/public interests (e.g., Manchester City Council, New East Manchester Ltd., Greater Manchester Police, Joint Health Unit, regional planning bodies), business (private sector casino complex provider, local developer, local businesses), and notfor-profit groups (religious groups, residents, community). This case represents good practice (Casino Advisory Panel, 2007), and the focal partner, as well as other partners on the project, has had significant direct experience with CSSPs over the past 20 years. Therefore, this rich, long-term case study provides sufficient, high-quality data to investigate the research questions in this study.

\section{Data Collection}

We develop a rich case history for the Manchester Super Casino CSSP and also gather data about prior CSSP projects in which all the partners were involved. The first author conducted interviews with 10 key representatives from nine partner organizations across the governmental, business, and not-for-profit sectors. As we show in Table 3, most of these participants were CEOs, managers, or leading representatives from the partners, many of whom were involved in the same interactions with regard to the CSSP. Together these participants were responsible for the development and implementation of the CSSP, and they participated in ongoing partnership structures in the focal geographic area.

\{Insert Table 3 around here $\}$

We stopped our interviews when we achieved saturation - that is, when extra interviews begin to yield few new insights (Strauss and Corbin, 1998). Each digitally recorded interview averaged 90 minutes in length (range: 45-120 minutes) and was transcribed, resulting in 240 single-spaced A4 pages. Our approach involved a constant comparative analysis. After each interview, we wrote theoretical memos as part of our theory-building process (Strauss and Corbin, 1998) to refine the research questions and provide a theoretical focus for the 
subsequent interviews. During the interviews, informants described their role in the super casino CSSP, responding to a mix of grand tour questions and floating prompts that aimed to reduce interviewer bias and allow for rich insights (McCracken, 1986). As the interviews progressed, it became clear that the informants agreed about the advanced, tri-sectoral nature of the project, so the interviews increasingly focused on understanding the nature of the interactions and management of the CSSP, as well as any prior CSSP experiences and learning by partner organizations and their impact on the super casino project. We also asked the informants about the factors they felt contributed to the success of the CSSP. During these phases, we undertook constant comparisons among emerging theory, new data, and prior literature, and this dialectical tacking drove our subsequent approaches. Then in subsequent interviews, we asked informants about the role of key individuals or other key internal or external influences during the CSSP process. Prior to each interview, the interviewer reviewed any publicly available secondary material to increase familiarity with the case. In all, we collected and reviewed 120 documents for this study (e.g., Final Report of the Casino Advisory Panel from 2007, Manchester Bid Proposal from 2006). These multiple sources improved the quality of our final interpretation and helped ensure triangulation (Beverland et al., 2010; Strauss and Corbin, 1998; Yin, 2003).

\section{Data Analysis}

Our analysis employed QSR: NUD*IST to keep track of the data, facilitate coding, and check for relationships. During the case analysis, we elaborated on the theoretical categories through open and axial coding procedures (Strauss and Corbin, 1998). Throughout, we also tacked back and forward between literature on CSSPs and organizational learning and the data, which led us to develop multiple theoretical categories and subcategories (Spiggle, 1994). We analyzed each interview transcript to gain a richer understanding of the 
interactions within the CSSP, prior partner experience, and learning about CSSPs, as well as the impact of such experience on the super casino CSSP.

During open coding, we read and examined discrete parts of the interview transcripts to identify similarities and differences. Each author undertook this analysis independently and classified each interview portion according to an initial coding scheme: CSSP, tri-sector, interactions, and influences on CSSP outcomes. The authors then met to discuss and reach agreement on any parts of the analysis subject to disagreement.

We applied axial coding to reassemble the data into categories and subcategories and thereby understand the role of the core components and capabilities. For example, with their unique and often particular characteristics, different partner groups tended to focus on the specific issues they believed were most appropriate and relevant for CSSP programs. Finally, we applied selective coding by integrating and refining the theory emerging from our data.

We also adopted several methods to improve the quality of our research (Beverland and Lindgreen, 2010; Lincoln and Guba, 1985; Strauss and Corbin, 1998). In particular, the four researchers each provided independent interpretations of the findings; we conducted multiple interviews; and the respondents had the opportunity to provide feedback on initial findings, all of which reinforced the reliability of our outcomes. In addition, only one researcher conducted all the interviews, which reduced the potential for bias.

\section{Findings}

Our findings are presented as follows. First, we consider the learning processes partners achieve through their prior experience. Second, we note the impact of experience and learning on the development and management of the Manchester Super Casino CSSP. Third, we apply these findings to derive an updated model of CSSPs.

\section{Learning Processes Based on Prior Experience}


The partners in this CSSP had developed several key learning exploration areas (March, 1991) from their experience over the previous 20 years. The ongoing relationships among partners in Manchester (governmental, business, and not-for-profit), which had worked effectively in the past, helped participants perceive the long-term benefits of such approaches. Some learning gained from prior CSSPs and exploited for the super casino CSSP appeared explicit (e.g., published strategy documents), whereas other forms clearly were tacit (e.g., CSSP philosophy). Partners noted the importance of seven exploratory learning areas in particular for the success of this CSSP: visionary leadership and a clear strategy; development of a CSSP philosophy; understanding partners' needs and priorities; developing long-term deep and trusting relationships; constructing a highly developed communication infrastructure; ensuring early engagement on any new projects; and ensuring high-quality personnel to support the CSSPs.

Learning area 1: Visionary leadership and a clear CSSP strategy. Many of the interviewed partners noted the importance of the chief executive of the council, Sir Howard Bernstein, with the support of the leader of the council, Sir Richard Lease, who provided visionary leadership. Sir Howard was frequently described as the driving force behind the council's CSSP strategy and the regeneration of Manchester:

Sir Howard has been really instrumental in bringing it all together. He was very instrumental in making sure the package was right for the local community, for the city as a whole, to secure something positive for the benefit of Manchester residents (Steve, residents' forum participant).

Generally regarded as a highly visible, charismatic, transformational leader, Sir Howard was very clear about the importance of the cross-sectoral partnerships as a means to achieve regeneration of East Manchester. The critical influence of this charismatic leader, in his position of significant power, is consistent with organizational change literature (Lawrence et 
al., 2005), which also notes the importance of leadership styles (Slater and Narver, 1995; Vera and Crossan, 2004). The CEO's open management style enabled "feed-forward" from individual members through to their group and the organizational level as part of the CSSP process. However, this CEO also was prepared to use his powerful position to institutionalize learning and drive organizational behavior through feedback mechanisms. This approach suggests the CEO wanted to ensure that the organization and its partners exploited exploratory learning from prior projects (March, 1991).

The evidence of individual to group learning processes included the CEO's attendance at many partner meetings and involvement in shaping projects. Through his team, he also remained aware of new project opportunities and the benefits of building long-term relationships with partners, which the other participants recognized: "It was driven from the top by Sir Howard. I have to say I was incredibly impressed by that man; he made things happen" (Paul, gambling CSR expert). Through his direct involvement in previous CSSPs, Sir Howard had explored directly the mechanics of such projects and some of their success factors. He was also very aware of the experiences of some of his "competitor" councils as they developed strategies for bidding on the casino project:

I think Howard had such an influence partly because of his personal qualities but also his experience, particularly with Manchester Millennium meant that he had very strong working relationships across a very wide range of interests in Manchester (Tom, CEO of New East Manchester Ltd.).

In turn, the council developed a very clear strategy for the regeneration of East Manchester and reviewed all possible projects in light of this long-term strategy. The casino project represented essentially a "regeneration vehicle" to the council that could bring investments into a deprived area. The city council already had learned that capital investments needed to regenerate East Manchester would have to come from the business sector and that any 
investment project needed the support of local businesses, as well as other not-for-profit community partners. The casino CSSP project was thus one more regeneration project, among a wealth of such projects, and thus part of a wider CSSP philosophy:

So you know we were very clear about what were the outcomes we were looking to deliver here ... how this fits with the well-established aspirations of the community, where this fits with some of the key stakeholders (Sir Howard).

Learning area 2: Development of a CSSP philosophy. The partners chose to adopt a CSSP philosophy because of their direct experience and exploratory learning with urban regeneration CSSP projects, since the early 1990s, because "Yes, we got established in the early days in the 1990s, developed a good understanding from council officers right the way up to Sir Howard" (Steve, residents' forum member). Public-private partnerships had long been a structural component of CSSPs, but over time, these partners also had explored the importance of non-contractual factors that could influence CSSP success. These soft elements were not detailed or documented, but their importance nevertheless was well understood by the partners.

For example, the gradual development of deep and trusting relationships among key partners meant that the super casino CSSP project could be likened to a conversation among partners, in which an ongoing dialogue and understanding already has been established: "A long history really, a long tradition of doing things in this way in Manchester, and consequently it was very much easier to have those kinds of dialogues across the sectors here. I think that did help the casino project" (Tom, CEO, New East Manchester Ltd.). Such mutual agreement about the desired outcomes (e.g., investment and regeneration, employment and training, reduced deprivation, profits) also underpinned the success of various CSSP projects. By developing a philosophy, the council and its partners already had built an environment that supported success at the individual CSSP project level. 
It is also notable that Manchester City Council, a public sector entity anchored to the Manchester area, has clear, long-term interest in this geographic location and tends to adopt a long-term perspective, with "what are known as strategic regeneration frameworks that have been the subject of extensive consultation with residents, with business, with the voluntary sector over a considerable period of time" (Sir Howard). This statement reinforces the longterm structural ties among the partners, as well as reflecting the ongoing partnership philosophy and clear long-term strategy for the region. Such a structuring of relationship interactions suggests a policy of exploiting former exploratory learning, in this case about high-quality interaction mechanisms.

Learning area 3: Understanding partners' needs and priorities. The ongoing CSSP engagement gave the council a good understanding of the general positions and needs of the various partners - a type of feed-forward from the individual, group, and partner organization level to the CSSP organization, in the form of the lead partner. Various groups received encouragement to engage and ensure their legitimate representation, which also helped the partners develop mutual understanding. That is,

People were encouraged to form groups to take part in community engagement, and even now to have a voice. The way forward is to actually listen to the local people who it's going to affect most (Steve, residents' forum member).

Such encouragement can be categorized as a call for feed-forward that provides insights, views, and learning from the bottom up. This feed-forward then shaped policy proposals by the council (feedback), which in turn were reviewed by all the partners in detail (feedforward). The council perceived its purpose was to improve the lives and livelihoods of the people of East Manchester; the other partners regarded its responsibility as serving various partners' needs. These respective roles were well understood and accepted. In this learning 
cycle then (Crossan et al., 1999), knowledge and understanding flowed up and down, both within and between partners.

The good level of understanding of partner needs and priorities developed through prior CSSP experiences and ongoing interactions; thus, the city council tended to propose investment projects that were more likely to be well received by partners, which facilitated cross-sector project development. In particular, the response to the idea of a super casino as a means to regenerate East Manchester, though it certainly raised some concerns, was enthusiastically welcomed:

The casino was key to regenerating the area of providing jobs, providing training and also would bring in a host of other leisure facilities, bars, restaurants, hotels and they were going to build a training centre on the site to bring people with a lower skilled base within the hotel sector up to an NVQ standard (Steve, residents' forum member).

Local partners understood the business partners needed a profit incentive to justify the investments required to regenerate East Manchester. Thus, the provision of a casino and other facilities in a major complex represented an acceptable trade-off to them. Partners seemed highly aware of the other partners' priorities and objectives, many of which were documented in published cross-sector material (e.g., Local Strategic Partnership, New East Manchester Ltd.). Such learning suggests movement along the CSSP continuum.

Learning area 4: Developing long-term, deep, trusting relationships. The Manchester City Council and other partners recognized the importance of establishing long-term, trusting relationships with key partners. The partners in the super-casino project thus agreed on the nature and importance of trusting relationships:

I think that historical relationships were fairly critical to be honest. Otherwise, I think people would have been very suspicious, they would have thought 'they are only wanting 
to talk to us because they have already decided what they want to do and they just want us to rubber stamp it' but that wasn't the case (Tom, CEO, New East Manchester Ltd.).

These long-term relationships reflected the nature of the dealings partners had previously experienced. Although relationship development was widely encouraged (feedback), the precise approach was difficult to formalize. Yet their importance was so widely acknowledged that relationships were developed and maintained (and exploited) even when there were disagreements and opposing views about specific element or strategies. Thus, the city council consistently was described by the CSSP partners as honest, credible, and straightforward: "Manchester City Council were genuine, were definitely listening and did take things on board and listened to the sorts of things that the faith groups were saying" (Rev. Stephen, faith group member). Of course, not all partners agreed with the use of a casino complex to regenerate East Manchester, because casinos and gambling are controversial activities. The faith groups in particular opposed the casino developments:

We didn't want a casino. We would never want a casino because we feel that it is wrong and in a sense it was against our beliefs, but we acknowledged the likelihood of it happening and therefore that's why we engaged in the process, if you like, as a critical voice, in order to challenge assertions over benefits and raise the profile of any sort of concerns over weaknesses (Rev. Stephen, faith group member).

Thus, partly on the basis of prior relationships and partially because these partners wanted to minimize societal risks associated with a major casino development, the faith groups agreed to play a significant role in the development of the social responsibility framework attached to the casino bid. Despite their opposition to casino development in general, the groups believed they had been genuinely consulted by the council and that their views had been acknowledged with regard to social responsibility concerns. The spirit of mutual respect for differing opinions helped build trust, in a clear example of how feed-forward from 
individuals and groups shaped policy and the direction. In this case, even views that did not align with the other partners' agendas were sought. Therefore, trusting relationships, which organizational learning literature deems influential in learning processes (Andrews and Delahaye, 2000), clearly encouraged the flow of knowledge throughout the super casino CSSP and therefore organizational learning among partners.

Learning area 5: Constructing a communication infrastructure. Exposure to previous CSSPs gave the partners experience with the best ways to communicate, which they exploited for the super casino CSSP. Generally, the partners had learned the importance of good communications, both long-term and project-specific, for trusting relationships and had developed a sophisticated communications infrastructure over the years. The regular schedule included residents' meetings, business forum meetings, and a local strategic partnership of more than 30 groups from the public, private, and not-for-profit sectors:

We had at that point been operating for probably four or five years and been operating a model, which had a high level of engagement anyway with local communities that again made it easier. There was an infrastructure for example of tenants and residents' associations which had been built up over a period (Sir Howard).

The communications infrastructure comprised ongoing, multilevel engagements with many complimentary and integrated contact points, as well as casino project-specific communications, which helped the council listen to its partner groups but also communicate its proposed development strategy. Thus, "Anything that was happening in New East Manchester came to the residents forum for consultation.... To make sure residents were being protected and also listened to" (Steve, residents' forum member).

The longer-term partnership entities also communicated to support the CSSP philosophy, enable broader participation, and foster good understanding. For example, as early as 1999, a 
partnership-based, nonprofit organization, the New East Manchester Ltd., had been established by the council to support the regeneration of East Manchester:

New East Manchester was a not for profit organization, a semi public body. I reported to a board of Directors which had a mix of private sector, public sector and community organizations represented on it, so although I was employed by the City Council I was effectively seconded to this partnership body (Tom, CEO).

This semi-public, hybrid governance body featured a membership board drawn from the public, private, and nonprofit sectors. It thus represented a formalized, ongoing, cross-sector partnership entity, and all proposed developments and initiatives for the area passed through this cross-sector board for debate.

Learning area 6: Ensuring early engagement in new projects. Prior experience and ongoing discussions through the well-established communications infrastructure revealed that the city council could support trusting relationships by being open, honest, and timely about possible new projects. Partners' engagement in the super casino project therefore took place at the earliest opportunity:

We had attended meetings of that [faith] group and we went and talked to the Bishop and said 'Look, we are thinking about this, we know your views but we need to talk about it, can we come along and do a presentation to your group and can we open up that dialogue?' (Tom, CEO).

Such early engagement represented a commitment, developed from the CSSP philosophy, as well as a desire for feed-forward from individuals and groups about possible projects. The council had learned and accepted that any East Manchester development strategy needed the involvement and support of various partner groups, such that "We recognized we needed to engage and talk to local people, local interests first and foremost" (Tom, CEO). 
Furthermore, as the lead partner, the council recognized that early dialogue supported a mutual approach to problem identification and resolution, as well as led to improved CSSP project performance. Without feed-forward from individuals, groups, and partners, the council would have lacked the information necessary to make sound decisions. Therefore, early dialogue-based learning exemplifies how the partners exploited knowledge they had gained in past CSSP interactions.

In turn, the early engagement was facilitated by the established communications infrastructure, which the partners had developed and supported over the years, such that "I think as soon as they thought it might be sort of viable that they came to us" (Justine, Police Commander). The local area Police Commander therefore was involved at an early stage and accepted her perceived role to raise any significant law and order concerns and work to provide solutions where necessary. The Police Commander also participated in the Local Strategic Partnership, such that she regarded herself as part of a "team effort" to regenerate the area. The policy of early, ongoing dialogue to share information also provided evidence of the respect among partners. Even though the council had a powerful position, as the bridge across many other partner groups, it acknowledged the need for mutuality and transparency (Lawrence et al., 2005). It had learned explicitly about the need for early partner engagement and dialogue about potential projects. Such lessons created an expectation among partners that it would take place; this early discussion then was facilitated by frequent interactions over the highly developed communications infrastructure.

Learning area 7: Ensuring high-quality personnel support CSSPs. Many of the partners commented on the quality of the CSSP team, which included representatives from the Manchester City Council, New East Manchester Ltd. (NEM), residents' groups, the casino provider Kerzner, and special advisors. These personnel, through years of experience, had become skilled at managing ongoing communication, as well as individual CSSP projects. 
Many projects in which the council and partners had been involved required competitive bidding or tendering for projects. Furthermore, the staff members understood the needs of partners within Manchester, as well as the expectations of external funding providers. This knowledge was not "a sort of systematic formula that you can apply, pick up and drop off somewhere else, a lot of it is about the individuals and personalities and the dynamic between that leadership group" (Ged, manager, Joint Health Unit).

If the council lacked the capabilities or knowledge in a specific area to make a credible case, it brought in specialists. For example, gambling corporate social responsibility was a specialized topic, so the council solicited the founder of Gamcare, "Paul Bellringer is a fantastic person. He was involved a lot with the responsible gambling unit and he has a wealth of knowledge and experience in that area" (Ian, project executive, NEM). By inviting specialist members from outside the organization, the Manchester CSSP benefitted indirectly from experience and learning gained through other CSSPs and in other contexts (Levitt and March, 1988). The city council ensured that the knowledge and experience of these specialists was captured (feed-forward).

The CSSP also benefited from the quality of representatives from the other partners, notably, the residents' groups, faith groups, gambling experts, the casino operator, the local developer (Ask Developments), and the local Police Commander. In our interviews, participants not only commented on the overall quality of personnel involved in the CSSP but also mentioned key individuals as influential for the CSSP success.

Beyond involvement and leadership skills of senior members of the partner organizations, they were responsible for developing a culture that supported credible teams. The manager of the Joint Health Unit (JHU), with years of experience with CSSPs in Manchester, thus suggested that in addition to high-quality personnel, the culture of the organization influenced success. Teams were responsible for setting and maintaining ongoing engagements with 
partners and maintaining relationships over the long term. The NEM teams in particular were portrayed as the delivery arm of the city council for regeneration projects. Moreover, the city council continually encouraged and motivated individual partners to represent the needs and interests of various groups. Exploiting the learning from prior CSSPs would not have been possible without high quality people representing each of the partner organizations. For example, the CEOs of the council and NEM Ltd. clearly established the CSSP philosophy and served as figureheads for the project, but the team of personnel within the various partner organizations made the project a reality.

\section{Impact of Experience and Learning on the Development of the Super Casino CSSP}

Many of the partners had prior partnering experience, whether in the governmental sector (city council, NEM, police, JHU), nonprofit sector (residents' associations, faith groups, Local Strategic Partnership, specialist advisors), or the business sector (business forum, casino venue operator, local property developers). This experience had a significant impact on the Manchester Super Casino CSSP by determining the partners' ability to plan and manage this project (Drucker, 1989; Waddock, 1991), as several partners indicated expressly. This overall finding reinforces Selsky and Parker's (2005: 858) observation that "learning is an important outcome of CSSPs," as succinctly summarized by a NEM executive: "Some of the people involved and some of the stakeholders have been equally involved in the successful bid for the commonwealth games, you could see that they had learnt from that successful experience and were now turning it to this" (Ian, project executive, NEM).

The Manchester partners had gained significant CSSP experience (Figure 2) and developed expertise, capabilities, and skills from project to project, which reflects the importance of a "willingness to learn and adapt" for successful CSSPs (Seitanidi and Crane, 2009: 424). A strong sense of organizational learning and organizational memory (Crossan et 
al., 1999) derived from past projects. The partners especially gained early exposure to CSSPs in the 1990s related to community engagement and understanding:

Right from the early days we have always known that community buy-in to change in neighbourhoods is fundamental and giving the community the opportunity to influence what we mean by change and to get them to understand the components of change is also a fundamental part as well (Sir Howard).

The history of the Manchester City Council's CSSP experience (Figure 2) began with the redevelopment of the Hulme housing estate, a project managed by a nonprofit partnership. Next, the Manchester Millennium partnership project aimed to renew the city center after a terrorist bomb decimated it. In 1999, NEM Ltd., a tri-sector partnership tasked with regenerating East Manchester, was established. A few years later, the opportunity for Manchester to bid to host the Commonwealth Games (2002) catalyzed more engagement with local communities and built skill and expertise related to competitive bidding. Manchester's success in this effort meant sport stadiums and facilities were built in East Manchester, as were relationships, skills, and capabilities. This project enabled the City Council to deepen its relationships with residents, local developers, and local business operators, which it did by exploiting its learning from earlier CSSPs. For example, "we would have probably set up some kind of process similar to the Commonwealth Games to award different supply contracts" (Ian, project executive, NEM). Other notable projects included attracting ASDA/Walmart to build its largest European store in East Manchester and guarantee local residents jobs at the store:

ASDA/Walmart was seen as a bit innovative, a lot of the employees were almost guaranteed to be local so the benefits of that store were kept within the neighbourhood quite well, and that model of kind of local training and labour retention was definitely something they were going to use in the regional casino (Ian, project executive, NEM). 
\{Insert Figure 2 around here $\}$

Partners thus looked back at the specific prior CSSP(s) that they had directly experienced to discern what had been successful and exploit these insights for future projects. One of those lessons taught the Manchester City Council to develop strong engagement infrastructures with local community groups, local developers, and private sector partners, so for the super casino, "We had the confidence of the private sector. The private sector was universally in support of what we were doing frankly, there was never any opposition to our proposals" (Sir Howard).

The partners themselves thus supported the notion of movement along a CSSP continuum of engagement and expertise, such that each successive CSSP provided learning and strengthened understanding and bonds among the partners, which then enabled longer-term, broadly oriented relationships (Selsky and Parker, 2005). In particular, successful innovations in one CSSP entered into the planning for the next (e.g., the ASDA/Walmart CSSP's recruitment policies, Commonwealth Games CSSP supplier contract awards). The partners explicitly recognized,

We were probably wet behind the ears when we did Hulme and probably we had to learn and improve as we did central Manchester, we had to get a lot better in terms of being in the city centre; the experience builds and the culture builds as well (Ged, manager, JHU).

Each project successfully navigated strengthened the partner bonds, trust, and relationships, as well as formalized the long-term partnership organizational entities and introduced an engagement infrastructure (e.g., Local Strategic Partnership, NEM Ltd.) that could support a long-term CSSP strategy and philosophy. These developments then pushed the search for other CSSP opportunities, including the Manchester Super Casino. The search for future projects relied on the use of local strategic regeneration frameworks, established 
with the cooperation of various partners. That is, the partners in East Manchester developed seven key learning areas over many years, all of which contributed to the success of the Manchester Super Casino CSSP. The impact of these learning areas appeared closely linked and multiplicative, such that the communication infrastructure furthered good relations, which supported a mutuality-based CSSP philosophy.

Such behavioral patterns reflect Waddock and Smith's (1991) argument that experience influences future interactions. The findings also reinforce an organizational learning perspective: Partner experience and learning over time allow for the exploration of different approaches, and then the exploitation of successful approaches or innovations later (March, 1991; see also Boguslaw, 2002; Huxham and Vangen, 2000).

Furthermore, though the learning relevant to the Manchester Super Casino CSSP was not formally managed, it was achieved through several key routes. The key personnel remained largely consistent over time, which reinforced organizational experience, memory, and learning. Even new personnel learned, through colleague and partner interactions and documentation, about prior CSSPs such as Hulme, ASDA/Walmart, and the Commonwealth games. Key figures often talked about past projects, which ensured the knowledge and learning was commonly understood. These various paths support theorizing about the routes to organizational learning (Crossan et al., 1999).

We also can consider the impact of historical experiences on the success of the Manchester Super Casino within the context of the early definition of organizational learning by Simon (1969: 236). The participants, through their interactions and prior CSSPs, clearly have learned how to frame their joint problems and manage their collaborations, which led to the development of communication structures and partnership entities. Furthermore, the findings confirm the importance of CEO leadership style (Slater and Narver, 1995; Vera and Crossan, 2004); approachability, trust, and credibility in relationships (Andrews and 
Delahaye, 2000); and the impact of power and political status for organizational learning (Lawrence et al., 2005).

Overall then, our findings support the notion of a continuum in CSSPs. The wealth of experience the partners gained from prior CSSPs allowed for their learning and improvement, deepened the relationships among partners, and increased levels of mutuality. Thus, whereas the Hulme CSSP was a singular, narrowly defined, short-term project, it encouraged the development of a CSSP strategy and increased levels of interaction, which started Manchester moving along the CSSP continuum. Even with our single case perspective, this study offers a strong argument that organizations, by learning from their prior direct and indirect experiences (Levitt and March, 1988), can move to more advanced levels on the CSSP continuum.

\section{Learning Model of CSSP Development and Implementation}

In line with the accusation that simple models of CSSPs (e.g., Seitanidi and Crane, 2009; Waddell and Brown, 1997) fail to capture the "messiness" of partnerships in practice (Selsky and Parker, 2005), our findings from the Manchester Super Casino CSSP suggest that prior models could be developed further. We also show that such modeling could be enhanced by the introduction of learning loops (Crossan et al., 1999), which represent a review process during the management and implementation of CSSPs and at the start or end of any single CSSP. Learning loops can take into account the partners' prior direct and indirect experience. Furthermore, such a model can depict the flow of CSSPs for organizations with a long-term philosophy to summarize lessons for future CSSPs. If organizations engage in multiple CSSPs simultaneously, they can draw experience and learning in both the short and long term. Finally, models should be more prescriptive and capture some best practice evidence from successful CSSPs. Therefore, our proposed model includes learning loops, as well as the 
seven learning areas for successful CSSP performance exploited by the Manchester Super Casino CSSP.

\{Insert Figure 3 about here $\}$

Furthermore, our analysis of prior literature on CSSP and organizational learning, together with our case study, implies that the model of organizational learning offered by Crossan and colleagues (1999), despite its general support in existing studies, requires the addition of a "supra-organizational" level to reflect the experiences of CSSP projects. That is, CSSPs go beyond individual organizations and introduce great complexity. Therefore, they demand coordination and management of several organizational partners. Individual and group organizational learning processes may be taking place within organizations (intraorganization) or between organizations (interorganization), such that the feedback and feedforward loops described by Crossan and colleagues (1999) entail further complications.

\section{Conclusions}

\section{Conceptual Contributions}

This research emphasizes the need to consider organizational experience and learning within the context of CSSPs. Organizational learning in our revised model takes the form of a formative learning loop (feed-forward) during a specific project, as well as a summative learning loop (feedback) at the end of the project to inform various partners about the successful and unsuccessful components of that CSSP (exploratory learning). Such learning can be exploited through institutionalization in new systems, procedures, and approaches for future CSSPs (feedback). Models of CSSPs must acknowledge the long-term orientation and experience of some CSSP partners as input variables for future CSSPs.

\section{Empirical Contributions}

Our rich case material draws on CSSPs in Manchester over a 20-year period and confirms the development of capabilities, skills, systems, and relationships over the course of several 
large- and small-scale CSSPs (Figure 2). The case findings strongly suggest that experience and learning enables progress along the CSSP continuum, from introductory to intermediate to advanced levels. We do not claim that a lack of prior experience of CSSPs prevents access to the intermediate or advanced levels, but that access is less likely. Organizations without prior experience can learn from others with CSSP experience, but the higher levels often require strong underlying relationships and mutuality between partners. Therefore, access to others' learning may not be enough to ensure success in demanding, complex CSSPs.

\section{Managerial Contributions}

Direct and indirect experience with CSSPs shapes the skills and capabilities of partners. In particular, we identify seven key success lessons derived from the Manchester Super Casino CSSP. However, experience does not guarantee learning (Crossan et al., 1999), so managers must recognize that they need to ensure a balance between new learning or exploration and exploitation to capitalize on what they have learned (March, 1991). Organizations should carefully manage and enable feed-forward (from individual to group to organizational levels), such that they translate insights, innovations, and ideas for use by the whole organization. Feedback (organization to group to individual) regarding adapted policies, rules, processes, and strategies simultaneously should be passed down the organization. Organizational learning is a dynamic flow (Crossan et al., 1999) that moves up and down the organization, so its handling must ensure learning is never blocked or interrupted en route.

The influence of the CEO and senior management team (Slater and Narver, 1995; Vera and Crossan, 2004) and internal politics and power games (Lawrence et al., 2005) can either enhance or interrupt this flow. The organization therefore should work to encourage the flow of information and learning, from individuals to groups and on to the organizational level. It also must continue to explore new learning, perhaps through experimentation with different approaches, rather than simply exploiting old knowledge that has been successful in the past. 
Finally, overly institutionalized, top-down organizations can drive out individual intuitions, which prevents them from learning in the future (Crossan et al., 1999).

\section{Limitations and Further Research}

This case study, though in-depth and extensive, including contributions from all key partners, relates specifically to a local governmental organization. In one sense, this focus represents a contribution to prior literature, which usually identifies a business organization as the central player (Bryson and Crosby, 2006). However, it also limits the applicability of our findings. Local governmental organizations are necessarily geographically specific, and their investments in long-term infrastructure, relationships, and CSSP orientation may be more easily understood and justified than they would be for a private sector, profit-based firm.

Furthermore, we have aimed primarily to extend CSSP literature by integrating literature from organizational learning. This integration prompts us to call for further research within the organizational learning field that investigates supra-organizational entities and thus offers clearer guidance about the learning process in these more complex organizational forms.

Finally, the prominent impact of prior CSSP experience and learning in the Manchester Super Casino case, as well as the strong CSSP orientation of key partners, implies that further research should consider whether CSSP philosophies are common in organizations. Historical research could be undertaken at the organizational level, rather than with regard to an individual CSSP case. This research would enhance our understanding of the organizational learning benefits for CSSP management success.

\section{References}

Alberic, P. and van Lierop, K. (2006), 'Sense and Sensitivity; The Roles of Organization and

Stakeholders in managing Corporate Social responsibility', Business Ethics: A European Review, 15(4), 339-351. 
Andrews, K.M. and Delahaye, B.L. (2000), 'Influences on Knowledge Processes in Organizational Learning: The Psychological Filter', Journal of Management Studies, 37(6), 797-810.

Astley, G. and Fombrun, C. (1983), 'Collective Strategy: Social Ecology of Organizational Environments', Academy of Management Review, 8(4), 576-587

Austin, J. (2000), The Collaborative Challenge, San Francisco, CA: Jossey Bass.

Barringer, B. and Harrison, J. (2000), 'Walking a Tightrope: Creating Value through Interorganizational Relationships', Journal of Management, 26(3), 367-403.

Berger, L., Cunningham, P. and Drumwright, M. (2004), 'Social Alliances: Company/NonProfit Collaboration', California Management Review, 47(1), 58-90

Beverland, M.B., Kates, S.M., Lindgreen, A., and Chung, E. (2010), 'Exploring Consumer Conflict Management in Service Encounters', Journal of the Academy of Marketing Science, 38(5), 617-633.

Beverland, M.B. and Lindgreen, A. (2007), 'Implementing Market Orientation in Industrial Firms: A Multiple Case Study', Industrial Marketing Management, 36(4), 430-442.

Beverland, M.B and Lindgreen, A. (2010), 'What Makes a Good Case Study? A Positivist Review of Qualitative Case Research Published in Industrial Marketing Management, 1971-2006’, Industrial Marketing Management, 39(1), 56-63

Boehm, A. (2005), 'The Participation of Businesses in Community Decision-Making', Business and Society, 44(2), 144-178.

Boguslaw, J.E. (2002), Social Partnerships and Social Relations. London, Routledge. Bontis, N., Crossan, M.M., and Hulland, J. (2002), 'Managing an Organizational Learning System by Aligning Stocks and Flows', Journal of Management Studies, 39(4), 437-469. Brady, T. and Davies, A. (2004), 'Building Project Capabilities: From Exploratory to Exploitative Learning', Organization Studies, 25(9), 1601-1621. 
Bryson, J.M. and Crosby, B.C. (2006), 'The Design and Implementation of Cross-Sector Collaboration: Propositions from the Literature', Public Administration Review, 66(Special Issue S1), 44-55.

Cangelosi, V.E.and Dill, W.R. (1965), 'Organizational Learning Observations: Toward a Theory', Administrative Science Quarterly, 10(2), 175-203.

Carroll, A.: (2004), 'Managing Ethically With Global Stakeholders: A Present and Future Challenge', Academy of Management Executive, 18(2), 114-120.

Casino Advisory Panel, (2007), Final Report of the Casino Advisory Panel, Uk Governement Department for Culture Media and Sport, at http://www.culture.gov.uk/cap/

Chapple, W. and Moon, J. (2005), 'Corporate Social Responsibility (CSR) in Asia: A Seven Country Study of CSR Web Site Reporting', Business and Society, 44(4), 415-441.

Crane, A. (2000), 'Culture Clash and Mediation', In J. Bendell (Ed.), Terms for Endearment. Sheffield, England: Greenleaf, pp. 163-177

Crossan, M.M.. and Berdrow, I. (2003) 'Organizational Learning and Strategic Renewal', Strategic Management Journal, 24(11), 1087-1105.

Crossan, M.M. Lane, H.W., and White, R.E. (1999), 'An Organizational Learning Framework: From Intuition to Institution,' Academy of Management Review, 24(3), 522537.

Daft, R.L. and Weick, K.E. (1984), 'Towards a Model of Organizations as Interpretation Systems', Academy of Management Review, 9(2), 284-295

DeGeus, A.P. (1988), 'Planning as Learning', Harvard Business Review, (March-April), 7074.

Dodgson, M. (1993), 'Organizational Learning: A Review of Some Literatures', Organization Studies, 14(3), 375-394. 
Drucker, P.E. (1989), 'What Can Businesses Learn from Nonprofits?', Harvard Business Review, (July-August), 88-93

Easterby-Smith, M., Crossan, M.M., and Nicolini, D., (2000), 'Organizational Learning: Debates Past, Present and Future', Journal of Management Studies, 37(6), 783-796.

Eisenhardt, K.M. (1989). 'Building Theories from Case Study Research', Academy of Management Review, 14(4), 532-550.

Elkington, J. and Fennell, S. (1998), 'Partners for Sustainability' Greener Management International, 24(Winter), 48-60.

Fiol, C.M. and Lyles, M.A. (1985), 'Organizational Learning', Academy of Management Review, 10(4), 803-813.

Gabriel, E. (2006), 'The Role of MNEs in Community Development Initiatives in Developing Countries: Corporate Social Responsibility at Work in Nigeria and South Africa', Business and Society, 45(2), 93-129.

Googins, B. and Rochlin, S. (2000), 'Creating the Partnership Society: Understanding the Rhetoric and Reality of Cross-Sectoral Partnerships', Business and Society Review, 105(1), 127-144.

Gray, B. (1989), Collaborating: Finding Common Ground for Multi-Party Problems, San Francisco, CA: Jossey-Bass.

Grunig, J.E. and Grunig, L.A. (1992), 'Models of Public Relations and Communication', in Grunig, J.E. (Ed.), Excellence in Public Relations and Communications Management. Hillsdale, NJ: Lawrence Erlbaum Associates, pp. 285-325.

Heugens, P., Van Den Bosch, F.A.J. and Van Riel, C.B.M. (2002), 'Stakeholder Integration', Business and Society, 41(1), 36-60. 
Huxham, C. and Vangen, S. (1996), 'Working Together: Key Themes in the Management of Relationships Between Public and Non-Profit Organizations', International Journal of Public Sector Management, 9(7), 5-17.

Huxham, C. and Vangen, S. (2000), 'Leadership in the Shaping and Implementation of Collaboration Agendas: How Things Happened in a (Not Quite) Joined Up World', Academy of Management Journal, 43(6), 1159-1175.

Kanter, R.M. (1998), 'Six Strategic Challenges', World Link, 11(1), 28-34

Kooiman, J. (1999), 'Social-Political Governance: Overview, Reflections and Design', Public Management, 1(1), 67-91.

Korten, D. (1998), Globalizing Civil Society: Reclaiming our Right to Power. New York, NY: Seven Stories Press

Lawrence, T. B., Mauws, M.K., Dyck, B., and Kleysen, R.F. (2005), 'The Politics of Organizational Learning: Integrating Power into the 4i Framework', Academy of Management Review, 30(1), 180-191.

Levitt, B. and March, J.G. (1988), 'Organizational Learning', Annual Review of Sociology, 14(1), 319-340.

Lincoln, Y.S. and Guba, E. (1985). Naturalistic Inquiry, Beverly Hills, CA: Sage.

Lindgreen, A. (2008), Managing Market Relationships. Farnham, England: Gower Publishing.

Lindgreen, A., Swaen, V., and Campbell, T.T. (2009), 'Corporate Social Responsibility Practices in Developing and Transitional Countries: Botswana and Malawi', Journal of Business Ethics, 90(3), 429-440.

London, T., Rondinelli, D.A., and O’Neill, H. (2005), 'Strange Bedfellows: Alliances Between Corporations and Nonprofits', In Shenkar, O. and Reuer, J. (Eds.), Handbook of Strategic Alliances. Thousand Oaks, CA: Sage, pp. 353-366. 
Maon, F., Lindgreen, and Swaen, V. (2010), 'Organizational Stages and Cultural Phases: A Critical Review and a Consolidative Model of Corporate Social Responsibility Development', International Journal of Management Reviews, 12(1), 20-38.

Maon, F., Lindgreen, A., and Vanhamme, J. (2009), 'Developing Supply Chains in Disaster Relief Operations through Cross-Sector Socially Oriented Collaborations: A Theoretical Model', Supply Chain Management: An International Journal, 14(2), 149-164.

March, J.G. (1991), 'Exploration and Exploitation in Organizational Learning', Organization Science, 2(1), 71-87.

March, J.G. and Olsen, J.P. (1975), 'Organizational Learning Under Ambiguity', European Journal of Policy Review, 3(2), 147-171.

McCracken, G. (1986). The Long Interview. Newbury Park, CA: Sage Publications.

Millar, C.C.J.M., Choi, C.J. and Chen, S. (2004), 'Global Strategic Partnerships between MNEs and NGOs: Drivers of Change and Ethical Issues', Business and Society Review, 109(4), 395-414.

Morsing, M. and Shultz, M. (2006), 'Corporate Social Responsibility Communication: Stakeholder Information, Response and Involvement Strategies', Business Ethics: A European Review, 15(4), 323-338.

Muthuri, J.N., Chapple, W. and Moon, J. (2009), 'An Integrated Approach to Implementing "Community Participation" in Corporate Community Involvement: Lessons from Magadi Soda Company in Kenya', Journal of Business Ethics, 85(2), 431-444.

Nelson, R.R. and Winter, S.G. (1982), An Evolutionary Theory of Economic Change. Cambridge, MA: Harvard University Press.

Nelson, J. and Zadeck, S. (2000), Partnership Alchemy: New Social Partnerships in Europe. Copenhagen, Denmark: The Copenhagen Centre. 
Nonaka, I., and Takeuchi, H. (1995), The Knowledge Creating Company, Oxford, England: Oxford University Press.

O’Regan, K.M. and Oster, S.M. (2000), 'Non-Profit and for-Profit Partnership: Rationales and Challenges of Cross-Sector Contracting', Nonprofit and Voluntary Sector Quarterly, 20(1), 120-140.

Oxley-Green, A, and Hunton-Clark, L. (2003), 'A Typology of Stakeholder Participation for Company Environmental Decision-Making', Business Strategy and Environment, 12(5), 292-299.

Perrini, F., Pogutz, S. and Tencati, A. (2006). Developing corporate social responsibility: A European perspective. Cheltenham, UK: Edward Elgar Publishing.

Polanyi, M. (1967), The Tacit Dimension. New York, NY: Anchor Books.

Roberts, N.C. and Bradley, R.T. (1991), 'Stakeholder Collaboration and Innovation: A Study of Public Policy Initiation at the State Level', Journal of Applied Behavioral Science, 27(2): 209-227.

Schildt, H.A., Maula, M.V.J. and Keil, T. (2005), 'Explorative and Exploitative Learning from External Corporate Ventures', Entrepreneurship Theory and Practice, 29(4), 493515.

Seitanidi, M.M. (2007), 'Intangible Economy: How Can Investors Deliver Change in Businesses? Lessons from Nonprofit-Business Partnerships', Management Decision, 45(5), 853-865.

Seitanidi, M.M. and Crane, A. (2009), 'Implementing CSR Through Partnerships: Understanding the Selection, Design and Institutionalization of Nonprofit-Business Partnerships', Journal of Business Ethics, 85(2), 413-429.

Seitanidi, M.M. and Lindgreen, A. (2008), 'Cross Sector Social Interactions', Journal of Business Ethics, 82(3), 525-526. 
Seitanidi, M.M. and Ryan, A. (2007), 'A Critical Review of Forms of Corporate Involvement: From Philanthropy to Partnerships', International Journal of Non-Profit and Voluntary Sector Marketing, 12(3), 247-266.

Selsky, J.W. and Parker, B. (2005), 'Cross-Sector Partnerships to Address Social Issues: Challenges to Theory and Practice', Journal of Management, 31(6), 849-873.

Simon, H.A., (1969), Sciences of the Artificial, Cambridge, MA: MIT Press.

Slater, S. and Narver, J. (1995), 'Market Orientation and the Learning Organization', Journal of Marketing, 59(3), 63-74.

Spiggle, S. (1994). 'Analysis and Interpretation of Qualitative Data in Consumer Research', Journal of Consumer Research, 21(3), 491-503.

Strauss, A., and Corbin, J. (1998), Basics of Qualitative Research: Techniques and Procedures for Developing Grounded Theory. Newbury Park, CA: Sage Publications

Steckel, R., and Simons, R. (1992). Doing Best by Doing Good: How to Use Public Purpose Partnerships to Boost Corporate Profits and Benefit Your Community. New York, NY: E.P. Dutton.

Vera, D., and Crossan, M.M. (2004), 'Strategic Leadership and Organizational Learning', Academy of Management Review, 29(2), 222-240.

Waddell, S. (1999), Business-Government-Nonprofit Collaborations as Agents for Social Innovation and Learning. Paper presented at the Academy of Management, Chicago, August.

Waddell, S. and Brown, L.D. (1997), 'Fostering Intersectoral Partnering: A Guide to Promoting Cooperation among Government, Business and Civil Society Actors'. IDR Reports, Boston, MA: Institute for Development Research.

Waddock, S. (1989), 'Understanding Social Partnerships. An Evolutionary Model of Partnership Organisations', Administration \& Society, 21(1), 78-100. 
Waddock, S. (1991), ‘A Typology of Social Partnership Organizations', Administration \& Society, 22(4), 480-516

Waddock, S.A., and Smith, N. (2000), 'Relationships: The Real Challenge of Corporate Global Citizenship', Business and Society Review, 105(1), 47-62.

Yin, R. (2003), Case Study Research, 3rd ed. Thousand Oaks, CA: Sage. 
Table 1: Cross-Sector Social Partnerships Definitions

\begin{tabular}{|c|c|c|}
\hline Author(s) & Definition & Key Aspects \\
\hline Kooiman (1999) & $\begin{array}{l}\text { All interactive arrangements in which public and } \\
\text { private actors participate to solve societal problems } \\
\text { or create societal opportunities and attend to the } \\
\text { institutions within which these activities take place. }\end{array}$ & $\begin{array}{l}\text { Public and private actors; } \\
\text { solutions to societal } \\
\text { problems; social } \\
\text { opportunities; governing } \\
\text { institutions. }\end{array}$ \\
\hline Muthuri et al. (2009) & $\begin{array}{l}\text { Business involvement in social initiatives by } \\
\text { contributing financial, in-kind, or human resources to } \\
\text { meet the social and economic needs of the } \\
\text { communities in which they operate. }\end{array}$ & $\begin{array}{l}\text { Business contributions; } \\
\text { social initiatives; } \\
\text { community needs. }\end{array}$ \\
\hline $\begin{array}{l}\text { Roberts and Bradley } \\
\text { (1991) }\end{array}$ & $\begin{array}{l}\text { A temporary social arrangement in which two or } \\
\text { more social actors work together toward a single } \\
\text { common end, which requires the transmutation of } \\
\text { materials, ideas, and/or social relations to achieve. }\end{array}$ & $\begin{array}{l}\text { Temporary; social actors; } \\
\text { work together; single } \\
\text { common end. }\end{array}$ \\
\hline $\begin{array}{l}\text { Selsky and Parker } \\
(2005)\end{array}$ & $\begin{array}{l}\text { Cross-sector projects formed explicitly to address } \\
\text { social issues that actively engage the partners on an } \\
\text { ongoing basis. }\end{array}$ & $\begin{array}{l}\text { Cross-sectoral; } \\
\text { addressing social issues; } \\
\text { ongoing. }\end{array}$ \\
\hline Waddock (1991) & $\begin{array}{l}\text { The voluntary collaborative efforts of actors from } \\
\text { organizations in two or more economic sectors in a } \\
\text { forum in which they cooperatively attempt to solve a } \\
\text { problem or issue of mutual concern that is in some } \\
\text { way identified with a public policy agenda item. }\end{array}$ & $\begin{array}{l}\text { Cross-sectoral; voluntary; } \\
\text { solving societal } \\
\text { problems; mutual } \\
\text { concern. }\end{array}$ \\
\hline
\end{tabular}

Table 2: CSSP Continua

\begin{tabular}{|c|c|c|c|}
\hline Authors & Introductory & Intermediate & Advanced \\
\hline \multicolumn{4}{|l|}{ Two-stage models } \\
\hline Selsky and Parker (2005) & Transactional & & Integrative \\
\hline Alberic and van Lierop (2006) & Inside-out & & Outside-in \\
\hline \multicolumn{4}{|l|}{ Three-stage models } \\
\hline Austin (2000) & Philanthropic & Transactional & Integrative \\
\hline Muthuri et al. (2009) & Traditional & Developmental & Relational \\
\hline Morsing and Shultz (2006) & Informing & Responding & Involving \\
\hline $\begin{array}{l}\text { Oxley-Green and Hunton-Clarke } \\
\text { (2003) }\end{array}$ & Informative & Consultative & Decisional \\
\hline
\end{tabular}

Table 3: Organizations and Respondents

\begin{tabular}{lllll}
\hline $\begin{array}{l}\text { Organization; } \\
\text { Respondent }\end{array}$ & $\begin{array}{l}\text { Stakeholder } \\
\text { Group (public, } \\
\text { private, nonprofit) }\end{array}$ & Mission (general) & $\begin{array}{l}\text { Role in Proposed } \\
\text { Regional Super } \\
\text { Casino }\end{array}$ & $\begin{array}{l}\text { Reason(s) for } \\
\text { Inclusion in Study }\end{array}$ \\
\hline $\begin{array}{l}\text { Manchester City } \\
\text { Council; Sir }\end{array}$ & Public & $\begin{array}{l}\text { To develop } \\
\text { innovative and } \\
\text { sustainable }\end{array}$ & $\begin{array}{l}\text { The developer of } \\
\text { the proposal. }\end{array}$ & $\begin{array}{l}\text { Manchester City } \\
\text { Council is the focal } \\
\text { organization driving }\end{array}$
\end{tabular}




\begin{tabular}{|c|c|c|}
\hline chief executive & & $\begin{array}{l}\text { regeneration } \\
\text { approaches that } \\
\text { become recognized } \\
\text { as best practices; } \\
\text { to establish a } \\
\text { CSSP engagement } \\
\text { infrastructure and } \\
\text { long-term } \\
\text { relationships with } \\
\text { partners. }\end{array}$ \\
\hline $\begin{array}{l}\text { New East } \\
\text { Manchester Ltd.; } \\
\text { Tom Russell, } \\
\text { former chief } \\
\text { executive; Ian } \\
\text { McCormack, } \\
\text { project executive }\end{array}$ & Public/nonprofit & $\begin{array}{l}\text { To develop } \\
\text { innovative and } \\
\text { sustainable } \\
\text { regeneration } \\
\text { approaches that } \\
\text { become recognized } \\
\text { as best practices. }\end{array}$ \\
\hline
\end{tabular}

Manchester Joint

Health Unit (City

Council and NHS

Manchester); Ged

Devereux, manager

Kerzner

Consortium; Tobin

Pryor, CEO

Responsibility in

Gambling Trust;

Paul Bellringer,

CBE

Greater Manchester

Faith and

Community Group;

Reverend Stephen

Williams

East Manchester

Residents' Forum;
Nonprofit

Public

Private consortium investors (casino operator and local developer, Ask Developments)

Nonprofit charity

Nonprofit community group community group
A hybrid governance, nonprofit organization developed in 1999 to manage to the development of East Manchester. A lead organization together with the City Council.

To develop initiatives to improve the health of residents in the Manchester area and reduce deprivation and inequality.

To provide innovative, attractive gambling services that profit the organization and benefit others in the process.

To ensure that the gambling industry develops with due regard to issues of social

responsibility and that vulnerable populations are protected and helped.

To ensure that the interests of faith groups are represented; to protect the vulnerable from the development of gambling.

To develop and enhance the East
Public sector organization with a stake in some potential social costs of a casino: increased crime, gambling addiction, and associated problems.

Private sector casino resort operator. The profitbased element of the project. Key investor of $£ 260 \mathrm{~m}$ for the project.

Expert advisor on social responsibility issues associated with gambling.

Critical voice toward the proposal. Opposed to casinos, but working to minimize any damage resulting from the development.

People living around the the project. It

chaired the panel proposing the project to the national government.

Implementation arm of the Manchester City Council, though still partner governed. Involved in many interactions with partners.

Key advisor regarding social responsibility unit developed to support casino development.

Sat on the panel proposing the project, attended many meetings.

A nonprofit organization involved in funding research and providing support for people with gambling problems. Attended many meetings and sat on the panel proposing the project.

A nonprofit stakeholder. Attended many key meetings and helped develop the social responsibility framework for the project.

A nonprofit stakeholder, directly 
Steve Green, chair and representative on NEM board.

Professor Peter Collins, director, Centre for the Study of Gambling and Commercial Gaming, University of Salford

Greater Manchester Police; Commander Justine Curran (now Chief Constable, Tayside Police)
Manchester area for the benefit of its residents; to provide sustainable jobs and enhance infrastructure and services.

Public, academic

To undertake research relating to the gambling industry

Public

To ensure the development of East Manchester and minimize any issues related to crime and disorder. development site

would be impacted

by the construction and the running of a major casino resort.

Expert advisor regarding gambling legislation and the social impacts of gambling.

\section{Supporter of} regeneration of Manchester while providing guidance regarding law and order issues. representing the

views of the community in which the project would be located. Attended many meetings representing community and sat on the panel representing project.

An academic and expert assessor involved in project meetings regarding social responsibility

Attended many meetings regarding the project and sat on the panel representing the project. 
Figure 1: Learning in Organizations: Four Processes through Three Levels

\begin{tabular}{|lll|}
\hline Level & Process & Inputs/Outcomes \\
Individual & Intuiting & Experiences, images, metaphors \\
& Interpreting & $\begin{array}{l}\text { Language, cognitive map, } \\
\text { conversation/dialogue } \\
\text { Group }\end{array}$ \\
Integrating & $\begin{array}{l}\text { Shared understandings, mutual } \\
\text { adjustment, interactive systems } \\
\text { Routines, diagnostic systems, rules and } \\
\text { procedures }\end{array}$
\end{tabular}

Source: Adapted from Crossan et al. (1999: 525) 
Figure 2: The History of Manchester City Council's CSSP Experience 
Figure 3: CSSP Planning Model 